Vol. 8, Issue 10, October 2021

DOI: 10.17148/IARJSET.2021.81008

\title{
THE STUDY OF NOISE POLLUTION IN INDIA
}

\author{
Prof. Bina Iyer \\ Assistant Professor, Nava Samaj Mandal Degree College, Dixit Cross \\ Road no. 1, Vile Parle ( east ), Mumbai - 400057
}

\begin{abstract}
Noise is a type of pollution and impacts on health and wellness of human beings in the world. Noise is defined as unwanted sound. The prevalence of noise is increasing severity because of the urban life style. The study identified vehicular pollution as one of the most cause of noise pollution and loud music as the second most important cause pf noise pollution in India. The study examines the problem of noise pollution in the wake of its ill effects on the life of the people. Noise produces direct and cumulative adverse effects that impart health and degrade residential, social and working environment with corresponding real and intangible losses. The noise as of late has risen as one of the essential poisons of condition. Noise has been a noteworthy supporter of irritation, which is substantiated by the aftereffect of ceaseless observing commotion at proportionate levels of public interest, training, administration, auxiliary outlining assumes a noteworthy part in noise administration. Noise represents an important health problem that can lead to hearing loss, sleep disruption, cardiovascular disease, reduce productivity, negative social behavior, annoyance reactions, absenteeism etc. Noise, adversely affects general health and well- being in the same way as does chronic stress. The aim of enlighted government control should be to protect citizens from the adverse effects of noise pollution.
\end{abstract}

Keywords : commotion, human, government, disruption, annoyance

\section{INTRODUCTION:}

Commotion might be characterized as a sound without pleasing melodic quality or as an undesirable sound. Noise is pressure oscillations in the air, water or any medium which radiates away from the source. Noise pollution is defined as a unwanted sound which gets dumped into environment and it adversely affects the health of a person and produces ill effect in living and non-living thing. In present day times, commotion is perceived as a genuine medical condition. Commotion contamination is the point at which the degree of clamor increments more than the typical level. Development of streets, structures, lofts and different regions are likewise bringing about expanding the commotion contamination. Clamor contamination impacts a huge number of individuals consistently. The most widely recognized medical issue it causes is Noise Induced Hearing Loss. ( NIHL) The high level of noise reduces the quality of work and thus reduces the concentration level. It causes different illnesses, for example, hypertension and mental problems to individuals as it upsets significant serenity.

Clamor recently has created as one of the basic toxins of condition.

One more issue of clamor defilement rose actually in India is an aftereffect of the unusual usage of intensifiers. Its erratic use from strict spots and in execution of strict capacities and talks occasionally makes it so problematic for everybody to make the most of their fundamental flexibilities with all human respect. The issue of clamor defilement has authoritatively crossed the danger point and uproar like exhaust cloud, is incapacitating as a moderate administrator of death.It is elusive, even in country regions, wherever where the main sound is those delivered by nature. Individuals are the typical receptors of clamor pollution. Regardless of the way that it is everything except hard to exhibit that ridiculous clamor could achieve the deficiency of hearing in individuals, it is difficult to show how much the effects of upheaval can win on individuals . Clamor can convey veritable physical and mental load on people.

\section{AIMS \& OBJECTIVE:}

To Study on Effects and the control of noise pollution in India and to evaluate the impact on environment of noise pollution.

1) To know a Effects Of Noise Pollution In India.

2) To Examine ways to control Noise Pollution.

3) To provide preventive and control measures on noise generated within our environment. 


\section{International Advanced Research Journal in Science, Engineering and Technology}

Vol. 8, Issue 10, October 2021

\section{DOI: 10.17148/IARJSET.2021.81008}

RESEARCH METHODOLOGY:

The study was undertaken through secondary data. This examination depends on auxiliary information which are gathered from a few sources like research papers, books, review articles, reports and various media.

\section{LITERATURE OF REVIEW:}

\section{Noise Pollution Control Strategy [2005] S.P.Singal :}

The future vision of a noise pollution in International of noise pollution various techniques available Effects the Impacts assessment technique Control measure the state of noise measurement practice in noise pollution . Awareness of the Noise pollution in India.

2. Environmental and justice [2004] C.M Jariwala : The causes of a noise pollution their affecting the and their serious problems of a noise pollution and there have characteristics of the noise and hazard their. Mental and social well-being the noise measures and the noise pollution by which their been taken and the serious vibrations of noise pollution.

Effects :The impacts of commotion contamination has an evil impacts on the people as well as on other living and nonliving things, which will be examined beneath.

Impacts of commotion obstruction with individuals' everyday routine : How clamor meddles with individuals' experiences. The age of nonsensical commotion inside the climate is viewed as a type of contamination since it brings down the personal satisfaction.

\section{1) Repeated interference with sleep:}

A much higher rate said they were stirred by extreme focus clamors, typically right on time around evening time when rest was not yet profound. After individuals have been sleeping for certain hours, they don't promptly awaken, in any event, when oppressed to extremely noisy clamors. Various individuals have various profundities of rest and they can conform to nighttime sounds. Without a doubt, nonetheless, boisterous conditions close to neighborhoods around evening time should be stayed away from absence of ceaseless rest has as check it. Numerous methods for sound protection are accessible today and can be applied at moderately unassuming cost.

\section{2) Effect on hearing or Deafness:}

These impacts possibly happen to genuine significance if the sounds are particularly noisy. Ceaseless openness to clamor levels much over $100 \mathrm{~dB}$ adversely affects hearing capacity inside a genuinely brief time frame. Numerous laborers who are presented to the commotion of stream airplane or extremely loud studios for even moderate periods before long foster perceivable hearing deformities.

\section{3) Effect on communication or speech Interference:}

Outer sounds can meddle with discussion and utilization of the phone, and well as the satisfaction in radio and TV projects and like side interests. It would thus be able to influence the effectiveness of workplaces, schools and different spots where correspondence is of imperative significance. The greatest acknowledged degree of commotion under such conditions in $55 \mathrm{~dB} .70 \mathrm{~dB}$ is viewed as exceptionally uproarious and genuine obstruction with verbal correspondences is inescapable.

\section{4) Mental or Physiological Effects:}

Many individuals grumble that commotion makes them deranged. Tests have been performed to endeavor to affirm or invalidate these cases. According to the H.M. Stationery Office report Noise; noise certainly does not contribute in the least to mental illness. Specialists and researcher have now restoratively affirmed that commotion upsets the natural living beings and their individual elements of the people. Fireworks and other extreme and constant explosives become actually agonizing leading to depression, psychological instability, cardiovascular infections, stomach ulcers and respiratory problems lessening human existence. Late explores have inferred that short openings to commotion (in overabundance of around $100 \mathrm{~dB}$ ) prompts antagonistic consequences for hatchling, migraine and, unsteadiness, tardiness in digestion tracts, stomach issues and impacts on visions to the degree that these on occasion become hopeless. 


\section{International Advanced Research Journal in Science, Engineering and Technology}

Vol. 8, Issue 10, October 2021

DOI: 10.17148/IARJSET.2021.81008

\section{5) Effects on Physical health and working efficiency or Psychological problems:}

Commotion has minimal actual impact on the organic exhibition given that the clamor level is beneath around 90 DB. Harm to the inward ear might result if constant commotion levels surpass around $100 \mathrm{~dB}$ as has been seen by the Doctors prompting actual sickness. Therapists and analysts have in late investigates have mentioned objective facts that commotion has certain connection with actual wellbeing causing strain bringing about issues like discourse obstruction, disturbance, weariness,sleep interference and emotional distress. Commotion levels in ventures causes impedance in effectiveness and correspondence and raises prospects of mishaps. World Health Organization has assessed momentous misfortune in the businesses every year.

\section{6) Effects on other animals and other living things :}

The impact brought about by ventures, rail lines, saltines, blasts and disturbance in the urban areas, airplanes and so on, can be felt on creatures, birds, mice, fishes and homegrown creatures for they are powerless to different impacts of because of openness clamor levels change their places. Birds avoid migrating to places where noise level is above 100 $\mathrm{db}$. The commotion outflows brought about by supersonic airplane, rail route clamor discharges and so on, may cause unnatural birth cycle in vertebrates and fishes just as birds are seen to have quit laying eggs. Consequently, to summarize creatures and other living things become vexed more than individuals and in the immediate reason for natural in balance.

\section{7) Effect on non-living things:}

Intense noise levels affect non-living things too. The clamor blasts cause breaks in public and archeological landmarks just as exceptionally significant degrees of commotion are the reason for breaks in slopes. Focused energy blasts can break glass sheets and vibrations in the structures. Examination work at India and abroad is being done as such as to get to its gravity on non-living things so safety measures could be taken forehand to lessen sway thereof.

\section{STATUTORY CONTROL OF NOISE POLLUTION:}

\section{Constitution of India}

Proper to Life:- Article 21 of the Constitution guarantees life and individual opportunity to all individuals. It is very much settled by rehashed declarations of the Supreme Court that privilege to life revered in Article 21 isn't of unimportant survival or presence. It guarantees an advantage of individuals to presence with human honorability. Anyone who wishes to live in peace, solace and calm inside his home has a privilege to keep the commotion as poison contacting him.

2. Criminal Procedure Code and Noise Control:- Provisions under the Sec. 133 of the Criminal Procedure Code, 1973 the Magistrate can make unforeseen solicitation requiring the singular causing bothering including that of disturbance to empty such

aggravation.

\section{Factories Act Reduction of Noise and Oil of Machinery:}

The Factories Act doesn't contain a specific course of action for upheaval control. what's more, 90 of the Act, clamor affected hearing hardship, is determined as notifiable ailment. In like manner, under the Model Rules, limits for commotion presentation for work zone an area have been suggested.

\section{Motor Vehicle Act.}

Arrangement Relation to utilization of horn and change of Engine: - In Motor vehicle Act rules in regards to utilize horns and any alteration in motor are made.

\section{Noise Pollution Control Rule 2000 under Environment Protection Act 1996:}

Energize for better heading for upheaval defilement There are The Noise Pollution (Regulation and Control) Rules, 2000 with a particular ultimate objective to actually look at the creating issue of clamor tainting the administration of India has sanctioned the noise contamination chooses 2000 that joins the going with rule game plans: -

The state government may classifications the territories in the modern or business or private 


\section{International Advanced Research Journal in Science, Engineering and Technology}

Vol. 8, Issue 10, October 2021

\section{DOI: $10.17148 /$ IARJSET.2021.81008 FINDINGS:}

- The existing enactments, that directly or indirectly relate to the matter of sound pollution in India are found inadequate to manage it on national level. Hence, there's ought to have some specific and effective legislation to manage sound pollution within the country which can be b

within the country which can be best suited to Indian culture and social set-up.

- Promulgation of noise standards from varied part sources at specific time of the day by the government.

\section{SUGGESTIONS /RECOMMENDATIONS:}

- Boycott modern and boisterous exchanges or works in neighborhoods.

- Award of pay to influenced people or individuals.

- Flying of air crafts, below a definite altitude, near the cities should not be allow except under emergency conditions.

- Fireworks especially those of exploding nature should be discouraged.

- Climate courts ought to be set up for control of commotion contamination.

\section{CONCLUSIONS:}

This paper explores the sources, effects and suggestions for controlling the excessive noise, industries, highway transport, airports, railways and public address system turns out to be major sources of noise pollution. In our life by knowingly or unknowingly every one of the possibilities for real time control of noise pollution.. This leads to marginal reduction of noise levels at the source. Another issue of noise contamination rose as of late in India is a result of the unpredictable utilization of amplifiers. Its random use from strict spots and in execution of strict capacities and talks once in a while makes it so problematic. The appropriate move will be made to constrict the clamor levels and controlling contamination. In future, state funded training, government and NGOs can assume huge part in controlling the clamor contamination. The occupants living there will undoubtedly experience the ill effects of medical issues and loser quality. According to the specialized perspective, it is important to take a few measures to lessen the clamor levels. Noise pollution is a silent attacker which is directly and indirectly responsible for health hazards, sickness and other ailments and loss of income due to reduced work. It has also added to the suffering firings of human beings. Environmental

corruption emerging from commotion contamination and different components has turned into a significant reason for stress for people in the future. One should not experiment with a system in a way that imposes unknown and potentially large risks on future generations. In order to do so, measures should be considered as reduction of speed limits, mainly near residential areas, schools and hospitals. Motivating forces might be given to the vehicle fabricates to foster new frameworks to lessen sound force outflows. Through the results obtained in the study its very evident that the city is suffering from severe noise pollution due to the vehicular traffic, industries contribute less concerned with increase in noise pollution. The Noise actually has ascended as one of the fundamental toxic substances of condition. Indeed, it needs the enactment to control and there are some local and state establishments which straightforwardly or in a roundabout way to identify with the issue of Noise be that as it may, there is no particular enactment in India. This is mainly attributed towards congested traffic area, unplanned road network, reduced one way traffic, construction of silence zone in the main area of the city, unplanned urban sprawl etc.

In most the areas the noise level is exorbitant with more than $85 \mathrm{db}$ average is prevailing across the city during the peak hour traffic, many schools, hospitals are situated in the heart of the city are also affected severely by the noise pollution. Evacuation of infringements and forbidding the utilization of air horns inside as far as possible.

\section{REFERENCE:}

1. Environmental Noise pollution noise mapping public health by Enda Murphy Eoiking

[2014].

2. Environment law in India by Mohammed Naseem [2011]

3. Noise pollution Control Strategy by S.P.Singal [2005].

4. Advanced and the Noise pollution Control by Lawrence wang Norman [2007].

5. Urban Environmental governance In India by K.v.Raju [2010].

6. The law relating to the pollution by James Mc. Laughlin [1972]. 